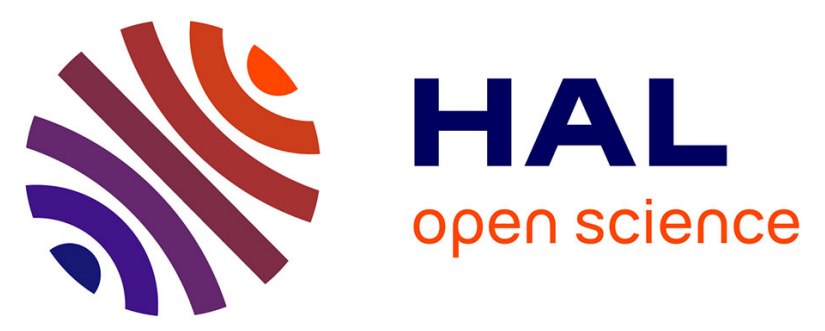

\title{
Microplastic and microfiber fluxes in the Seine River: Flood events versus dry periods
}

Robin Treilles, Johnny Gasperi, Romain Tramoy, Rachid Dris, Anaïs Gallard, Chandirane Partibane, Bruno Tassin

\section{- To cite this version:}

Robin Treilles, Johnny Gasperi, Romain Tramoy, Rachid Dris, Anaïs Gallard, et al.. Microplastic and microfiber fluxes in the Seine River: Flood events versus dry periods. Science of the Total Environment, 2021, pp.150123. 10.1016/j.scitotenv.2021.150123 . hal-03335861

\section{HAL Id: hal-03335861 \\ https://hal-enpc.archives-ouvertes.fr/hal-03335861}

Submitted on 21 Jan 2022

HAL is a multi-disciplinary open access archive for the deposit and dissemination of scientific research documents, whether they are published or not. The documents may come from teaching and research institutions in France or abroad, or from public or private research centers.
L'archive ouverte pluridisciplinaire HAL, est destinée au dépôt et à la diffusion de documents scientifiques de niveau recherche, publiés ou non, émanant des établissements d'enseignement et de recherche français ou étrangers, des laboratoires publics ou privés. 
3 TREILLES Robin ${ }^{1 *}$, GASPERI Johnny ${ }^{2}$, TRAMOY Romain ${ }^{1}$, DRIS Rachid ${ }^{1}$, GALLARD

4 Anaïs $^{1}$, PARTIBANE Chandirane ${ }^{1}$, TASSIN Bruno $^{1}$

5

$6{ }^{1}$ Leesu, Ecole des Ponts, Univ Paris Est Creteil, Marne-la-Vallee, France

${ }^{2}$ GERS-LEE Université Gustave Eiffel, IFSTTAR, F-44344 Bouguenais, France

*Corresponding author: robin.treilles@enpc.fr

11 Abstract

12 Studies on the influence of hydrodynamic conditions on anthropogenic microfiber (MF) and 13 microplastic (MP) distributions in freshwater environments are sparse. In this study, we 14 studied the influence of urbanisation gradient on the spatial variability of MFs and MPs. Temporal variability was also assessed by comparing the concentrations and fluxes of MFs and MPs under low flow conditions with those during the January-February 2018 flood event.

17 For each period, Seine river water was collected upstream and downstream of Greater Paris and filtered through an $80 \mu \mathrm{m}$ net at three different sampling sites. MFs were counted using a stereomicroscope, while MPs were analysed using micro-Fourier transform infrared spectroscopy coupled with siMPle analysis software. The highest concentrations of MFs and MPs were reported at the furthest downstream sites during both periods. However, high water flowrates and urbanisation gradient did not significantly impact MF and MP concentrations, sizes, or polymer distributions. The median MF and MP concentrations were 2.6 and 15.5 items $/ L$ and their interquartile ranges were 1.6 and 4.9 items $/ L(n=10)$, 
respectively, illustrating relatively stable concentrations in spite of the urbanisation gradient and variations in the flowrate. In contrast to the concentration, size, and polymer distribution characteristics, MP mass fluxes were strongly affected by river flow. MF and MP fluxes show increases in the number and mass of particles from upstream to downstream. The downstream site presents high MP mass fluxes, which range between 924 and 1675 tonnes/year. These results may indicate significant MP inputs from the Paris Megacity through wastewater treatment plant effluents and untreated stormwater. The JanuaryFebruary 2018 flood event, which represented 14.5\% of the year (in terms of time), contributed $40 \%$ of the yearly MP mass fluxes. Thus, flood events contribute strongly to MP fluxes.

KEYWORDS: microplastic, microfiber, microlitter, plastic pollution, flood, hydrological conditions

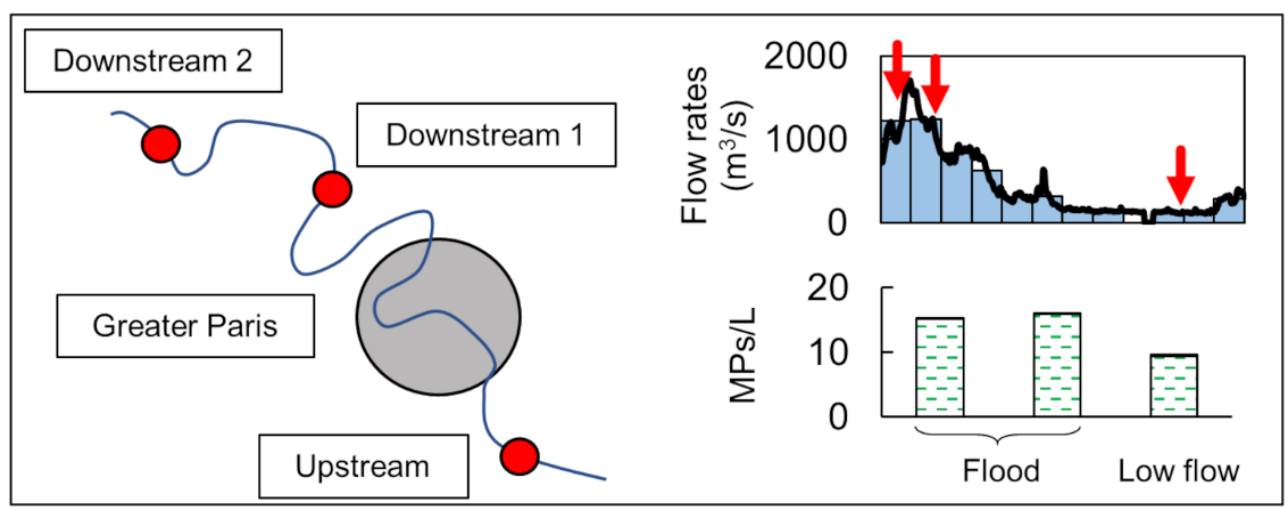

1. Introduction

Microlitter, such as microfibers (MFs) and microplastics (MPs), represent a threat to marine

41 (Cole et al., 2011; Gall and Thompson, 2015; Jamieson A. J. et al., 2019) and freshwater environments (Blettler et al., 2017). An increasing number of studies have investigated the transport of microlitter in freshwater environments. The development of microlitter analysis in environmental matrices such as surface waters (Horton et al., 2017) and sediments (Klein et al., 2015) has led to significant advances in assessing the concentration of these particles. 
However, very few studies have been conducted on the influence of hydrological conditions and urbanisation gradients on microlitter concentrations in rivers.

Several studies have observed higher concentrations of microlitter during low-flow periods than in high-flow conditions (de Carvalho et al., 2021; Rodrigues et al., 2018; Watkins et al., 2019; Wu et al., 2020). This difference in concentrations was attributed to a dilution effect. Other studies did not observe significant differences in microlitter concentrations between low and high-flow conditions (Schmidt et al., 2018; Wagner et al., 2019). According to these studies, other parameters may influence the microlitter concentrations. Several studies did not evaluate variation linked to flowrate seasonality, but focused on the impact of rain events during low-flow conditions. Hitchcock (2020) showed that under low-flow conditions, the MP concentration of a small urban estuary river increased during two days of heavy rain, from 400 particles $/ \mathrm{m}^{3}$ to 17000 particles $/ \mathrm{m}^{3}$. Wong et al. (2020) observed a correlation between MP concentrations and precipitation in freshwater environments and noted a strong impact of runoff on MP distribution. Rain events may increase the MP input in rivers owing to the leaching of soil and sealed surfaces. Rain events can lead to combined sewer overflows and untreated stormwater discharge to rivers (Blettler et al., 2017). Thus, rain events may induce a flushing effect, that is, an increase in the MP input to freshwater resulting from mismanaged urban water (Schmidt et al., 2018). Other studies have suggested that there is no simple correlation between river flow and MP concentration (Kataoka et al., 2019; Wagner et al., 2019). Kataoka et al. (2019) observed a correlation between MP concentrations and water quality, but no relationship between MP concentrations and flowrates. Other studies have shown that flood events may play a key role in plastic debris loads in rivers (Roebroek et al., 2021; Tramoy et al., 2020b). Veerasingam et al. (2016) observed a significant increase in MP pellet concentrations in beach sediments after a flood event. These pellets may have been remobilised and more easily migrated from land to sea. Hurley et al. (2018) showed that a significant amount of the MP load stored in channel-bed sediments was exported after a flood. According to these studies, MPs may be efficiently 
flushed from the river to the sea during a flood. Anthropogenic MFs are rarely considered in these studies, even though they are ubiquitous contaminants (Zhao et al., 2016). Thus, the relationship between microlitter concentration, flow rates, and precipitation is still debated.

Several studies concerning the influence of the urbanisation gradient have observed higher MP concentrations in urbanised, densely populated, and downstream areas (Kataoka et al., 2019; Schmidt et al., 2018; Wagner et al., 2019; Wu et al., 2020). In several of these studies, MP concentrations were correlated with population density (Kataoka et al., 2019; Wu et al., 2020). According to Wagner et al. (2019), plastic concentrations may be constant in rural areas but increase linearly in urban areas owing to inputs associated with urban discharge during rainy weather. Rodrigues et al. (2018) observed higher concentrations upstream of the catchment studied. This observation may be a particular to the sampling site, as the upstream part of the catchment studied has a higher population density (Rodrigues et al., 2018). However, Wong et al. (2020) observed no correlation between MP concentrations and population density. Thus, various conclusions may be drawn, depending on the sampling site.

In this study, MF and MP concentrations were estimated at three different sampling sites upstream and downstream from Greater Paris during low flow conditions, as well as during a flood event that occurred in January-February 2018. The main objectives of this work were to evaluate the influence of the urbanisation gradient and different hydrological conditions on the MF and MP concentrations and fluxes.

\section{Materials and methods}

\subsection{Sampling sites}

Three sampling sites were selected: (i) the first site, noted "Upstream", is located $100 \mathrm{~km}$ upstream of Paris (Greater Paris, 8.9 million capita, $2546 \mathrm{~km}^{2}, 3700 \mathrm{cap} / \mathrm{km}^{2}$ ) and downstream of the moderately dense city of Troyes (Troyes Champagne Metropolis, 98170167 capita, $889 \mathrm{~km}^{2}, 191 \mathrm{cap} / \mathrm{km}^{2}$, with a waste water treatment plant capacity of 260 
000 population equivalent) ; (ii) the two other sites are located 20 and $45 \mathrm{~km}$ downstream of

100 Paris and noted as "Downstream 1" and "Downstream 2", respectively. Upstream is less

101 impacted by industrial activities, whereas Downstream 1 and 2 correspond to a dense

102 urbanised area. Downstream 1 is located downstream from three significant waste water

103 treatment plants (noted as WWTP, "Seine Centre", "Seine Amont" and "Marne Aval", which

104 have treatment capacities of 240000,600000 and $75000 \mathrm{~m}^{3}$ per day, respectively),

105 Downstream 2 is located downstream of the most significant WWTP of Paris Megacity

106 (Seine Aval, which has a treatment capacity of $1700000 \mathrm{~m}^{3}$ per day, according to the

107 Parisian Public Sanitation Authority) and is also located downstream of the confluence

108 between the Seine River and Oise River, which is one of its main tributaries (Figure 1). The

109 major potential sources of microplastics are: (i) Combined Sewer Overflows (CSO) of

110 Greater Paris, (ii) Waste Water Treatment Plants (treatment capacity $>75000 \mathrm{~m}^{3}$ per day),

111 (iii) untreated stormwater, and (iv) densely populated areas with intense industrial activities

112 near the different sampling sites.

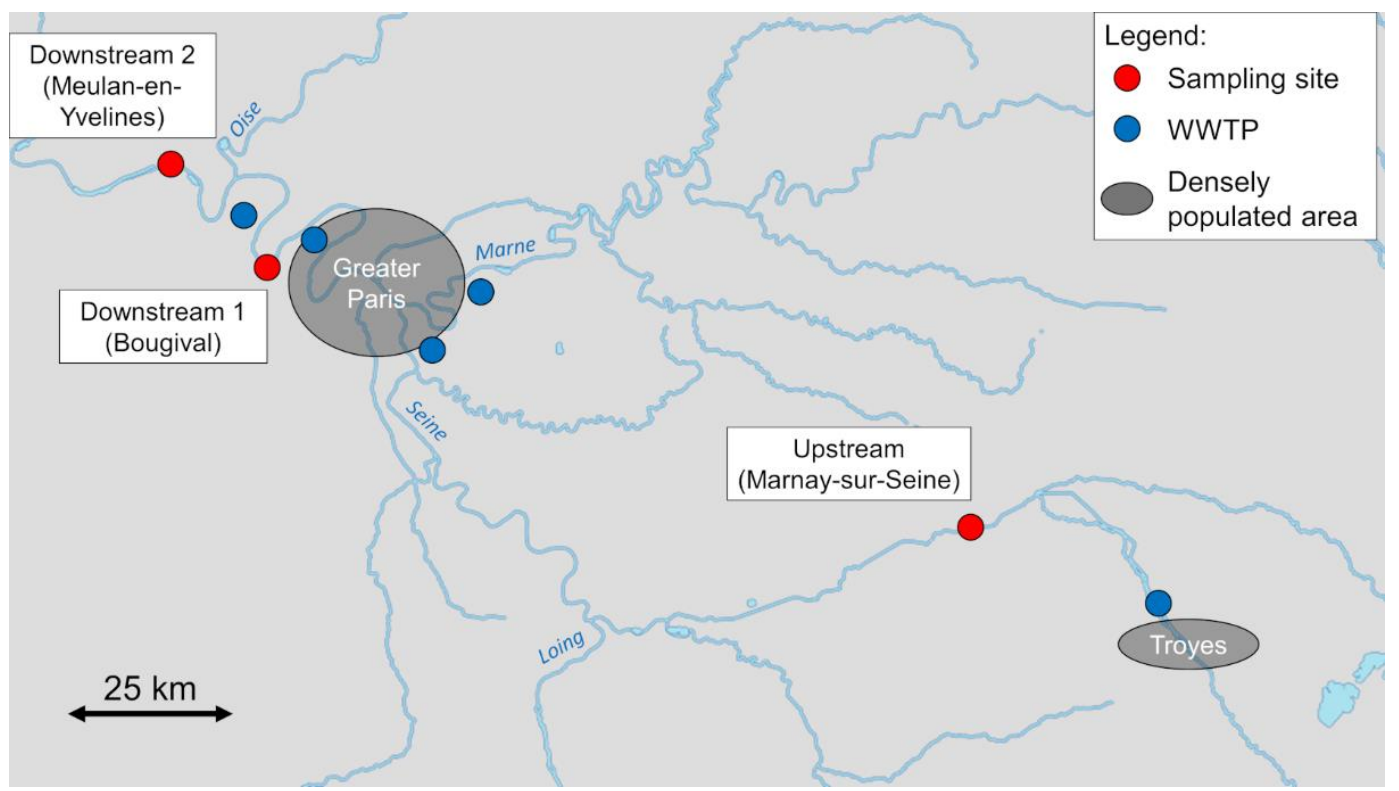

114 Figure 1: Location of the sampling sites, most significant Wastewater Treatment Plants

115 (WWTPs, treatment capacity $>75000 \mathrm{~m}^{3}$ per day) and densely populated areas (the

116 hydrographic network is from Geoportail France). 
118 Three sampling campaigns were performed during contrasting hydrological conditions: two 119 campaigns were conducted during the flood event that occurred in January-February 2018, represented by the numbers 1 and 2 in Figure $2\left(01 / 26 / 18\right.$ and 02/21/18, $Q_{\max \text { Paris }}=1710$ $\mathrm{m}^{3} / \mathrm{s}$, with a 10 year return period of $Q_{10}=1650 \mathrm{~m}^{3} / \mathrm{s}$ and a 100 year return period of $Q_{100}=$

$1222400 \mathrm{~m}^{3} / \mathrm{s}$ ) and one campaign was conducted during the dry season during a low water level 123 period, represented by the number 3 in Figure $2\left(07 / 17 / 18, Q_{\text {Paris }}=155 \mathrm{~m}^{3} / \mathrm{s}\right)$. The Seine

124 River was monitored by a surveillance network that followed the flow variations (Figure 2).

125 Samples were collected at each site during the same day in the following order: Upstream, 126 Downstream 1, and Downstream 2. One extra sample was collected on 02/21/18 from the 127 Upstream sampling site (2 bis, green arrow in Figure 2). The first campaign (01/26/18) 128 corresponded to a period of increasing flow just before the flow peak. The following 129 campaign in February 2018 corresponded to a decrease in the water flowrate. The daily 130 flowrates and water levels of each sampling campaign are presented in the supplementary 131 data (Table S1). Between 20 and $30 \mathrm{~L}$ of water were manually collected from the bridges 132 using a metal bucket and filtered through an $80 \mu \mathrm{m}$ net. Plastic materials were banned to 133 avoid any on-site contamination. The net was systematically rinsed before and after 134 sampling. The samples were then stored in glass containers in a cold room $\left(4^{\circ} \mathrm{C}\right)$. 

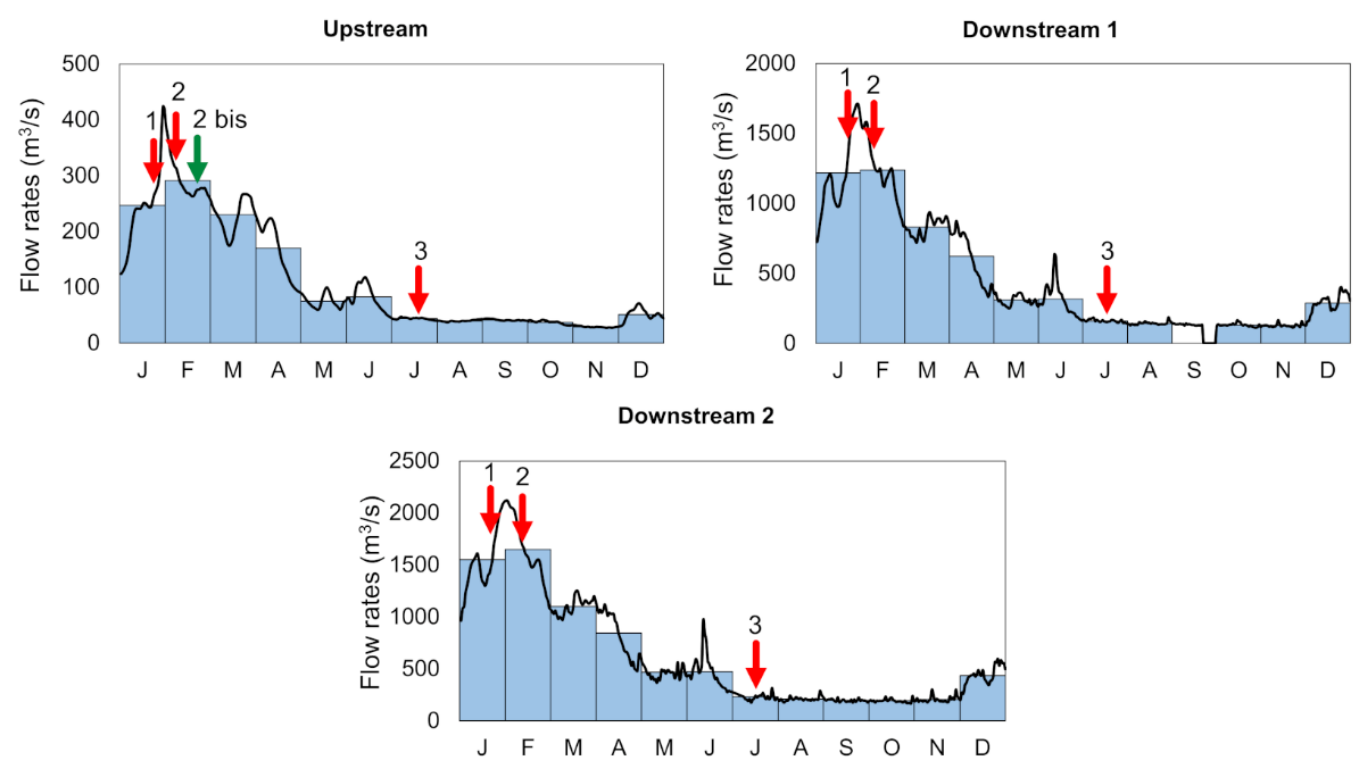

136 Figure 2: Daily flowrates (black lines) and monthly mean flowrate (blue bars) of the different

137 sampling sites for 2018. Date of sampling is represented by the red arrows (data from

138 http://hydro.eaufrance.fr, Upstream, Downstream 1 and Downstream 2 flowrates were 139 assessed using Pont-sur-Seine, Austerlitz and Vernon measurements, respectively). The 140 green arrow indicate the extra sample collected at the Upstream sampling site.

142 Samples were sieved using a $5 \mathrm{~mm}$ and a $1 \mathrm{~mm}$ sieve and separated into the $1-5 \mathrm{~mm}$

143 fraction and $<1 \mathrm{~mm}$ fraction. Sieving did not prevent the entrance of long fibers $(>5 \mathrm{~mm})$ in

144 the $<1 \mathrm{~mm}$ fraction, owing to their small diametres. Particles in the $1-5 \mathrm{~mm}$ fractions were

145 inspected under a stereomicroscope. Based on their colour, shape, and texture, suspected

146 plastic particles were set aside and characterised using infrared spectroscopy with

147 attenuated total reflectance (ATR-FTIR, Thermo ScientificTM iD7 accessory). This method is

148 based on Dris et al., 2017. For the $<1 \mathrm{~mm}$ fraction, organic matter was oxidised using 30

149 wt $\% \mathrm{H}_{2} \mathrm{O}_{2}$ digestion at $40^{\circ} \mathrm{C}$ for $48 \mathrm{~h}$ with $50 \mathrm{~mL}$ of solution and magnetic stirring (300 rpm).

150 Digestion was conducted at temperatures $\leq 40^{\circ} \mathrm{C}$ to avoid thermal degradation of the MFs

151 (Treilles et al., 2020). The solution was filtered through a metallic filter $(\varnothing=90 \mathrm{~mm}$, porosity

$152=14 \mu \mathrm{m})$. MP particles were then separated from mineral matter by densimetric separation 
in a Nal solution $\left(\rho \geq 1.6 \mathrm{~g} \cdot \mathrm{cm}^{-3}\right)$ in a separating funnel. The supernatant was filtered using

154 the same metallic filters and the microlitter was characterised.

155 Because of their shapes, the automatization of MF detection with $\mu \mathrm{FTIR}$ and processing software cannot be implemented confidently. Indeed, confusions between MFs and MP fragments were frequently observed with automated $\mu$ FTIR detection. For this reason, all MFs were manually counted under a stereomicroscope (Leica MZ12, with a size detection limit of $50 \mu \mathrm{m}$ ) coupled with an image analysis software (Histolab) according to the method developed by Dris et al. (2018), while MPs were counted and chemically characterized by $\mu F T I R$ imaging, with no shape distinction. MFs are all anthropogenic fibers, including synthetic and non-synthetic fibers. This results in possible crossed data between MFs and MPs. However, we decided to keep the data in this form, as the size distribution between MPs and MFs is significantly different (Figure 5). Indeed, most of MPs are below $250 \mu \mathrm{m}$ whereas MFs are above $1000 \mu \mathrm{m}$ (Figure 5). This overlap of data may thus be negligible. Once the MFs were counted, metallic filters were plunged in a crystallizer with $20 \mathrm{~mL}$ of filtered water and the particles were removed using an ultrasonic bath for $30 \mathrm{~s}$. The filtered water was then poured into a $100 \mathrm{~mL}$ glass bottle. This resuspension step was repeated three times. Then, the metallic filter was rinsed one last time with $40 \mathrm{~mL}$ of filtered water. The glass bottle was vigorously stirred for $1 \mathrm{~min}$ to homogenise the content. Then, 10 to 20 $\mathrm{mL}$ of this volume, i.e., 10 to $20 \%$, was filtered onto a Whatman® anodisc inorganic filter membrane (porosity: $0.2 \mu \mathrm{m}, \varnothing 25 \mathrm{~mm}$, with a filtration surface of $\varnothing 14 \mathrm{~mm}$ ). The anodisc filters were analysed with Fourier transform infrared spectroscopy coupled with

174 a microscope, using the Thermo Scientific Nicolet ${ }^{\mathrm{TM}} \mathrm{iN10} \mu \mathrm{FTIR}$ in transmission mode. A

175 Thermo Scientific $®$ MCT/A Cooled Imaging detector with a spectral range of 4000 to $1200 \mathrm{~cm}^{-1}$ was used to avoid interference with the anodisc filter. An autobaseline correction was applied to all spectra. After the spectral background was defined, the mapping analysis mode was used on one scan. All particles on three $6 \times 6 \mathrm{~mm}$ infrared maps were analysed, corresponding to $70 \%$ of the filtration surface of the filter. An atmospheric suppression correction was applied to all spectra. Maps were analysed using the siMPle analysis 
181 software developed by Aalborg University, Denmark and the Alfred Wegener Institute,

182 Germany (Liu et al., 2019).

183 This method has a size detection limit of $25 \mu \mathrm{m}$. Each spectrum identified as a plastic 184 polymer by the siMPle software was checked by an operator for false positives. Particular 185 attention was paid to PE spectra, as false positives of these particles have been observed in other studies (Witzig et al., 2020). siMPle assesses the number of particles and estimates an order of magnitude for the mass and volume of MPs, as detailed in Kirstein et al., 2021. MP concentrations were extrapolated to the initial sampling volumes. Because the number of samples remained small, non-parametric statistics were used in the analysis. Several precautions were applied to mitigate contamination. Glass vessels and filters were all heated to $500^{\circ} \mathrm{C}$ for $2 \mathrm{~h}$ before use. All solutions used were filtered on GF/D Whatman glass fibre filters (Sigma Aldrich, porosity: $2.7 \mu \mathrm{m}$ ). The vessels were rinsed with filtered water and filtered using $50 \%$ ethanol. Laboratory coats of $100 \%$ cotton were worn and plastic materials were avoided. The samples were stored in glass bottles. Glass bottles and all beakers were covered with aluminium foil. The samples were sieved using a laminar flow cabinet. Contamination during the different extraction steps was evaluated using procedural blanks $(n=10)$, which underwent the same steps as the samples.

3. Results and discussion

3.1. Microfiber and microplastic concentrations

During the flood event, MF concentrations ranged between 1.3 and 3.7 items/L, whereas MP concentrations ranged from 10.4 to 34.4 items/L (Figure 3 ). In low flow conditions, MF concentrations ranged from 1.9 to 5.5 items/L, whereas MP concentrations ranged from 9.3 to 26.5 items/L (min-max values). Median MF contamination was 0.3 items/L with an interquartile range of $0.2(n=10)$ whereas median MP contamination was 0.2 items $/ L$ with an interquartile range of 0.2 (Figure 3 ). each sampling site, under low flow conditions and during the flood (variation in concentration 

$=($ Max-Min $) /$ Min $){ }^{*}$ 100) (Table 1). Upstream and Downstream 1 presented relatively low

209 variations between the minimum and maximum concentrations for both MFs $(<25 \%)$ and 210 MPs (<71\%) (Table 1). Downstream 2 presented the highest MF (229.8\%) and MP 211 concentrations (318.0\%) (Figure 3) and the highest variability between minimum and 212 maximum values (Table 1).

213 Table 1: Variation in concentrations between minimum and maximum values for each 214 sampling site, for samples collected in low flow conditions and during the flood

\begin{tabular}{|l|r|r|}
\cline { 2 - 3 } \multicolumn{1}{c|}{} & $\begin{array}{l}\text { \%Variation between } \\
\text { min-max values for MFs }\end{array}$ & $\begin{array}{l}\text { \%Variation between } \\
\text { min-max values for MPs }\end{array}$ \\
\hline Upstream & 14.4 & 49.0 \\
\hline Downstream 1 & 23.3 & 70.3 \\
\hline Downstream 2 & 318.0 & 229.8 \\
\hline
\end{tabular}

216 If all samples are combined, we obtain MF and MP median concentrations of 2.6 and 15.5

217 items/L and interquartile ranges of 1.6 and 4.9 items/L, respectively $(n=10)$. Other studies

218 in freshwater environments generally have found concentrations below 1 items/L (de

219 Carvalho et al., 2021; Kataoka et al., 2019; Wong et al., 2020). The concentrations we found 220 are comparable to those found in Cooks River, Australia (between 0.4 and 17.4 items/L, 221 Hitchcock, 2020) and in the Maozhou River, China (between 3.5 and 25.5 items/L, Wu et al., 222 2020). We found that MPs were more abundant than MFs. Several studies have also reported fewer fibers than other shapes in freshwater samples (Mani and Burkhardt-Holm, 224 2020; Mao et al., 2020; Wu et al., 2020). Stereomicroscope counting did not enable the 225 detection of MFs below $50 \mu \mathrm{m}$. Therefore, we may have underestimated the MF 226 concentration. Despite a strong urban gradient and high water flow variability between 227 sampling sites, MF and MP concentrations during low flow conditions have the same order of magnitude as the concentrations estimated during the flood event of January-February 
2018 (Figure 3 and Table 1). Downstream 2 presented the highest variability (Table 1) and

230 the highest concentrations (Figure 3) of MPs and MFs, both during low-flow conditions and 231 the flood event. This may indicate a significant release of MPs related to WWTPs. However, 232 Downstream 2 is located downstream the confluence with the Oise River (Figure 1), which was also flooded. This tributary is less urbanised and may dilute the microlitter inputs at this sampling site. However, the flood event did not significantly change the concentrations observed at the different sampling sites. As previously noted, contradictory results were found regarding the influence of water levels and flows on MP concentrations. The dilution of MPs during flood events has been reported in several studies (Rodrigues et al., 2018; Watkins et al., 2019; Wu et al., 2020), but does not seem to occur in the Seine River. Recent studies have shown that stormwater runoff could be a significant source of macroplastics

240 (Treilles et al., 2021b) and microplastics during rain events (C. Liu et al., 2019; Treilles et al., 2021a). Precipitation may increase microlitter inputs through stormwater runoff. The increase in the flowrate during a flood implies remobilisation of the sediments owing to an increase in 243 the shear strength, as well as remobilisation of MF and MP stored in sediments (Hurley et 244 al., 2018). However, in the Seine River, waterway traffic may greatly influence this distribution. In 2019, 23.7 millions of tons of goods were transported by waterway traffic in the Seine River basin (Voies Navigables de France, 2020). This intense activity influences the sediment dynamics, which are not in a steady state (Vilmin, 2014). Waterway traffic intensively remobilises sediments even under low-flow conditions. This could partially explain the similar values observed between the flood and low-flow conditions. To ensure better comparability between studies, waterway traffic and sediment dynamics in a study area should be precisely recorded. The concentrations found in the Seine River are very high compared to those presented in a previous study on this river ( $3 \times 10^{-4} \mathrm{MPs} / \mathrm{L}$; Dris et al., 2015). The Seine River concentrations are also high compared to those found in the Rhine ( 1 × 10-3MPs/L ; Mani et al., 2015). Contrary to Wong et al. (2020), we found no statistically significant correlations between precipitation and concentration (Spearman's rs test, $p=0.89$ ). 

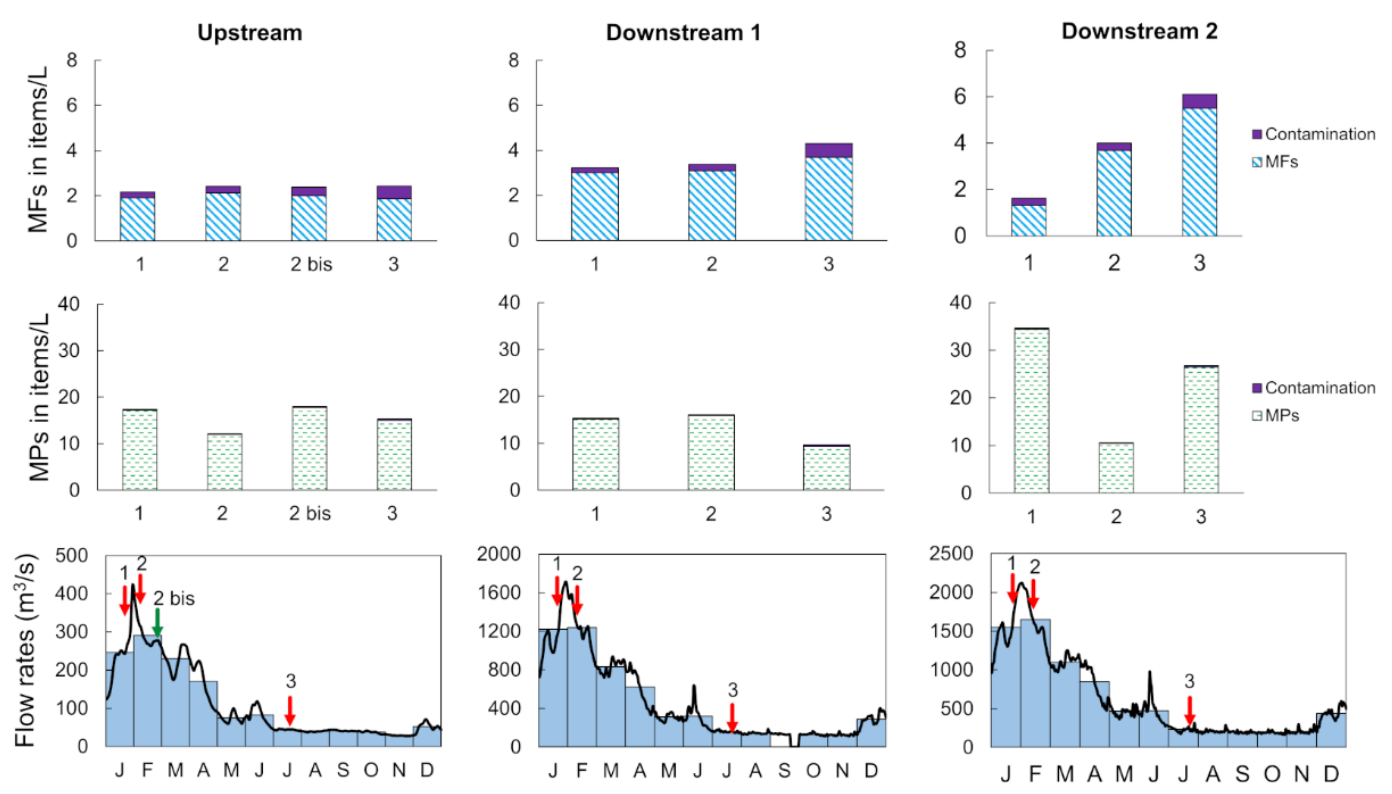

258 Figure 3: Microfiber and microplastic concentrations in the Seine river, relative to the

259 hydrograph of each site (y-axis are different depending on the sampling site)

260 Regarding the spatial variations, concentrations between the upstream and downstream

261 areas were of the same order of magnitude. This is consistent with previous data collected

262 by Dris et al. (2018), who did not notice a significant impact of the urban gradient or

263 variations in the flow rate on the MF or MP concentrations in the Seine River. These

264 observations were confirmed by the present study at a larger scale. Based on the size and

265 shape of the particles, the siMPle analysis software enables MP mass concentration estimates. However, it was not possible to estimate the mass of the MFs that we counted using a stereomicroscope. The order of magnitude for MP mass concentrations was comparable between the low flow period and the flood event, as shown in Table 2. We did not observe a significant concentration gradient between the upstream and downstream sites of Greater Paris in terms of mass concentrations, which is consistent with the results of

271 Dris et al. (2018). In addition, Downstream 2 presented the highest mass concentrations in number of particles (Table 2). MP mass concentrations in freshwater environments have

273 been only rarely estimated. Using the total weight/number of microplastics and non-metric

274 multidimensional scaling (nMDS), Rodrigues et al., 2018 reported mass concentrations

275 between 5 and $51.7 \mu \mathrm{g} / \mathrm{L}$ in Antuã River, Portugal. These values were comparable to our 
estimations. Several studies have reported lower mass concentrations. In surface water

277 samples, Haberstroh et al. (2021) found a mean mass concentration of $5.4 \mu \mathrm{g} / \mathrm{L}$ in the

278 Hillsborough River, USA. Kataoka et al. (2019) observed variable MP mass concentrations

279 between 0 and $3.2 \mu \mathrm{g} / \mathrm{L}$.

280 Table 2: Estimation of MP mass concentrations in Seine River water based on siMPle 281 software analysis.

\begin{tabular}{|l|c|c|}
\cline { 2 - 3 } \multicolumn{1}{c|}{} & $\begin{array}{l}\text { Median mass concentration } \\
\text { during low flow period }(\mu \mathrm{g} / \mathrm{L})\end{array}$ & $\begin{array}{c}\text { Median mass concentration } \\
\text { during the flood event }(\mu \mathrm{g} / \mathrm{L})\end{array}$ \\
\hline Upstream & 10 & 20 \\
\hline Downstream 1 & 5 & 10 \\
\hline Downstream 2 & 80 & 50 \\
\hline
\end{tabular}

282

3.2. Microfiber and microplastic size distribution

284 Boxplots of the MF and MP sizes relative to river discharge are shown in Figure 4. The size distribution of these particles under low-flow conditions and during the flood event is presented in Figure 5. During the flood event, the median MF sizes of Upstream,

Downstream 1, and Downstream 2 samples ranged from 1960 to $5410 \mu \mathrm{m}$, whereas the median MP sizes ranged from 115 to $205 \mu \mathrm{m}$ (Figure 4). The MF size distribution showed the presence of large MFs $>5 \mathrm{~mm}$ (Figure 5).

In low-flow conditions, the median MF sizes of Upstream, Downstream 1, and Downstream 2 samples ranged from 2500 to $3480 \mu \mathrm{m}$, whereas the median MP size ranged from 96 to 248 $\mu \mathrm{m}$ (Figure 4). As for the flood event, the MF size distribution showed the presence of large MFs $>5 \mathrm{~mm}$ (Figure 5). In contrast, the median MP size was below $250 \mu \mathrm{m}$. The MF and MP size distributions during the flood and low-flow conditions are detailed in the supplementary data (Table S2 and Table S3). The mean values were always higher than the median values owing to the presence of large particles (> $5 \mathrm{~mm}$ for MFs and $>1 \mathrm{~mm}$ for MPs) (Figure 4). 

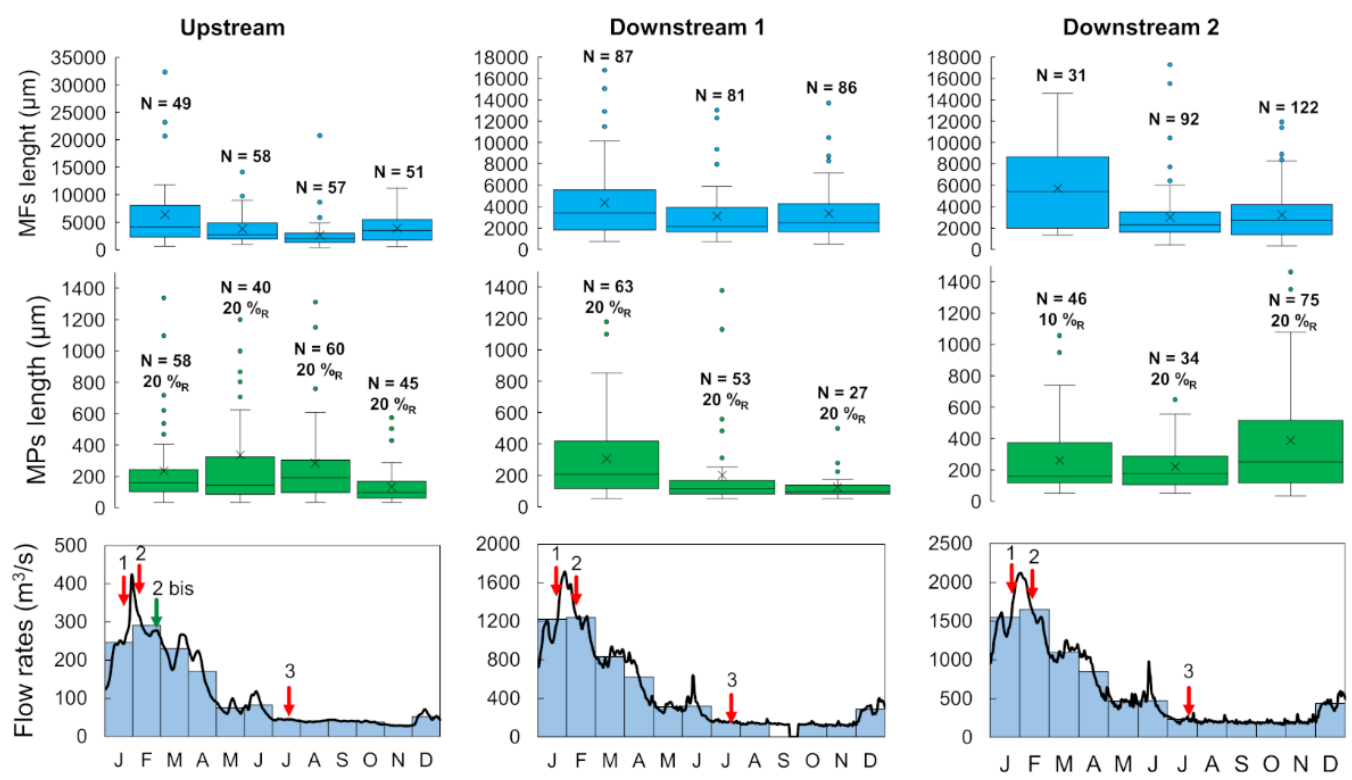

298 Figure 4: Boxplots of microfiber and microplastic length relative to the hydrographs of each

299 sampling site (y-axis may be different depending on the sampling site); mean values are

300 displayed as crosses; \%R: resuspension percentage; N: number of particles
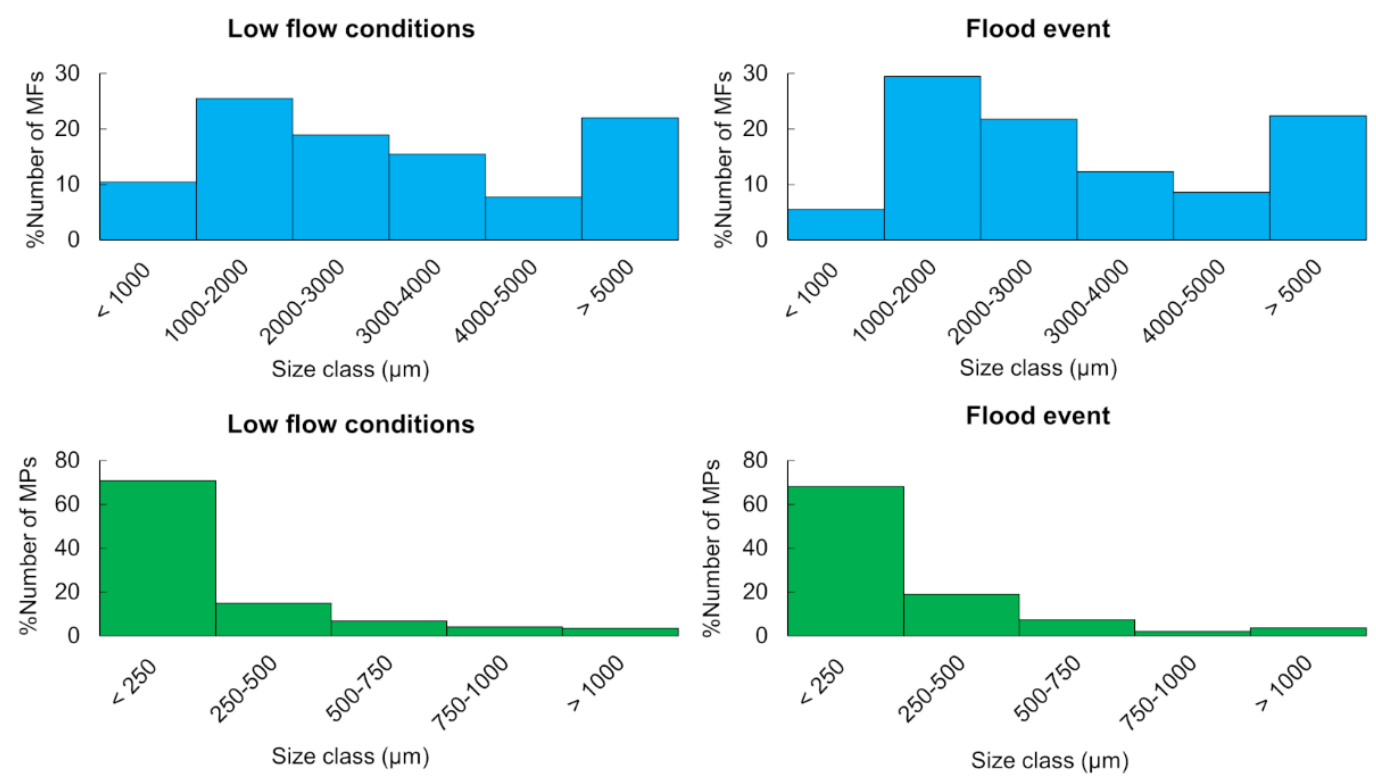

302 Figure 5: Microfiber and microplastic size distributions in low flow conditions and during the 303 flood event

304 According to Figure 5, the size distributions in low-flow conditions and during the flood event

305 are similar. MFs sizes were not significantly different between times of low river discharge and floods, according to the Mann-Whitney test $(n=259$ in low flow conditions and $n=455$ 
during the flood; $p=0.33$ ). The same trend was observed for MPs (MW test, $n=147$ in low-

308 flow conditions and $n=354$ during the flood; $p=0.09$ ). MFs and MPs found in the analytical

309 blanks were significantly smaller than the particles analysed in the samples (MW test, p

$310<0.05)$. The median number of MF and MP found in each analytical blank was 9 and 4 ,

311 respectively, with a median size of $1800 \mu$ m and $104 \mu \mathrm{m}$, respectively $(n=10)$.

312 More than $20 \%$ of MFs belonged to the $>5 \mathrm{~mm}$ size class (Figure 5 ). The minimum and 313 maximum MF sizes of all the samples were 313 and $32328 \mu \mathrm{m}$, respectively. Even though

314 more than $60 \%$ of MFs are smaller than $4 \mathrm{~mm}$, the $<1 \mathrm{~mm}$ size class is not the most

315 abundant, in contrast with the size distribution of MFs found in atmospheric fallout (Allen et

316 al., 2019). This size distribution differs from that found in a previous study on the Seine

317 River, for which $>1 \mathrm{~mm}$ was the most significant fraction (Dris et al., 2018).

318 More than $60 \%$ of MPs were smaller than $250 \mu \mathrm{m}$ (Figure 5). This shows the importance of 319 using a small mesh size for MP sampling. A $300 \mu \mathrm{m}$ net may be inefficient in collecting the most significant MP size classes. The minimum and maximum MP sizes of all samples combined were $32 \mu \mathrm{m}$ and $2528 \mu \mathrm{m}$, respectively. When all samples were combined (for low flow periods and during the flood), $20 \%$ of all MPs were smaller than $80 \mu \mathrm{m}$. This may indicate that: (i) the $80 \mu \mathrm{m}$ net clogged and stored small MPs or (ii) MP aggregates with various MP sizes could have accumulated in the net and could have been separated during organic matter digestion.

\subsection{Polymer distribution}

Polypropylene (PP) is the most common polymer (56-90\%), followed by polyethylene (PE, 3-19\%) and polyester (PES, 0-26\%) in all samples (Figure 6). The category "other" from Figure 6 contains seven polymers, as detailed in the supplementary data (Table S4). For all samples, PP was always the most abundant polymer. PP and PE are commonly used in packaging, while PES is used in plastic bottles and textiles. 

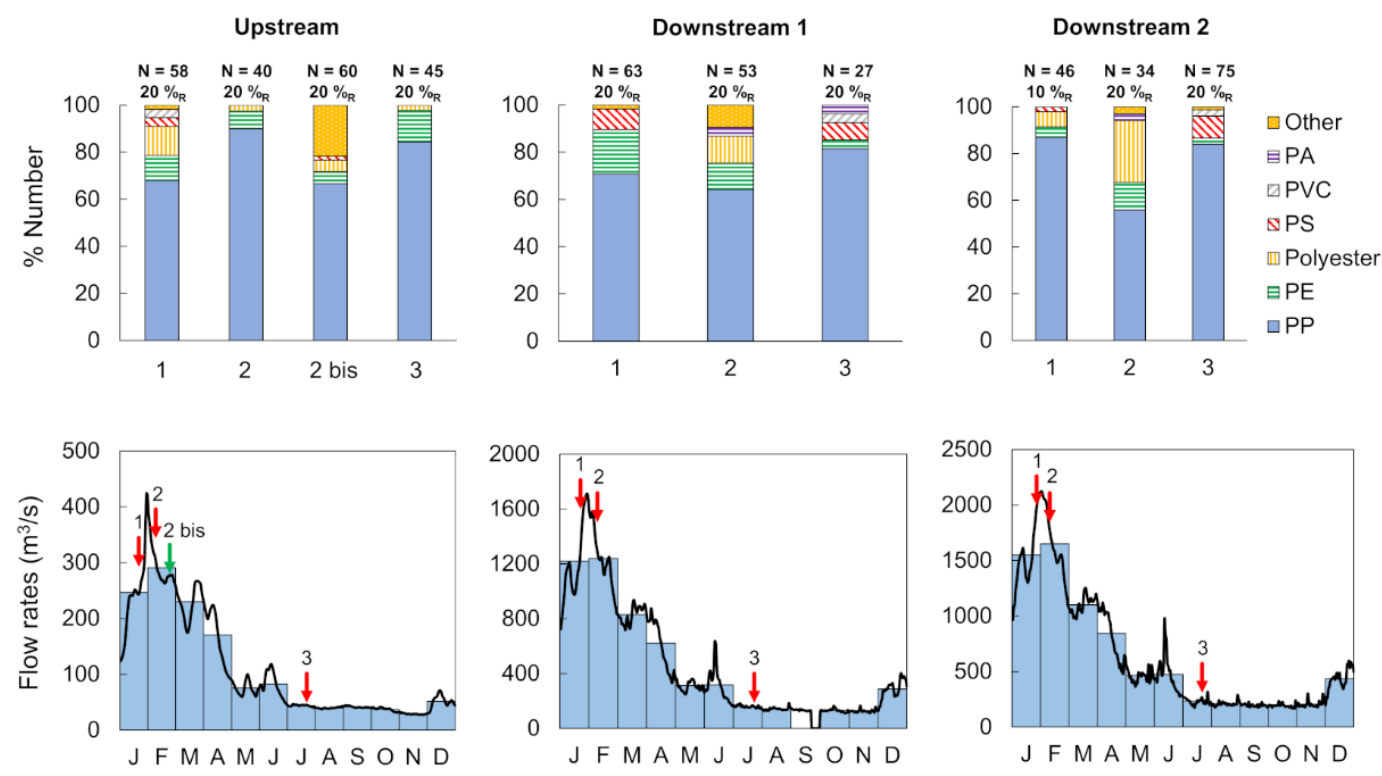

333 Figure 6: Percentage of polymers in each sample relative to river discharge at each site. $\mathrm{N}$ :

334 number of microplastics (MP) particles found for a given resuspension volume; \%R:

335 resuspension percentage. PP: polypropylene; PE: polyethylene; PS: polystyrene; PVC:

336 polyvinyl chloride; PA: polyamide;

337 The results do not show significant differences in polymer distributions between low flow conditions and the flood event (Figure 4-6, Table S4). The most significant polymers found in our samples (PP, PE, PES) are the same as the most representative polymers of macroplastic debris found in rivers (van Emmerik et al., 2018). These macroplastics may have formed MPs through fragmentation, which could explain the similarity in the polymer nature between these studies. The flood event had no significant impact on the type of

343 polymer transported.

3.4. MPs and MFs fluxes in the Seine river

345 These similarities between low flow conditions and floods have strong implications for MF and MP fluxes in the Seine River. Considering the daily flowrates of each sampling site

347 (assessed using Pont-sur-Seine, Austerlitz, and Vernon measurements, respectively; see 348 Figure 2) and the MF and MP concentrations (first and third quartiles, see supplementary data Table S6), we calculated the MF and MP fluxes as the number of particles flowing per 
year in the Seine River. We assumed that the MF and MP distributions were the same over

351 the water column. For both MF and MP fluxes, we observed an increasing gradient from

352 Upstream to Downstream 2 (Table 3).

353 The MF flux ranges from $6.6 \times 10^{12}$ to $9.1 \times 10^{13}$ items/year, increasing from Upstream to

354 Downstream 2 (Table 3). Dris et al. (2018) previously estimated an anthropogenic MF flux in 355 the Seine River between $2.8 \times 10^{10}$ and $6.1 \times 10^{11}$ particles/year. With the hypothesis that $35665 \%$ of the MFs are synthetic, they approximated a flux between $1.8 \times 10^{10}$ and $4.0 \times 10^{11}$ of 357 synthetic MFs per year. Owing to a lack of data, Dris et al. (2018) considered only fibers and 358 not the fragments. We estimated much higher fluxes for anthropogenic MF fluxes. This 359 difference may be linked to methodological differences between our studies. Samples from 360 Dris et al. (2018) were collected with an $80 \mu \mathrm{m}$ net plunged into the Seine River, while we 361 pre-filtered raw water with an $80 \mu \mathrm{m}$ net. This sampling difference may affect the 362 concentrations observed in samples, as reported by Zheng et al. (2021), who found a difference in concentration of two orders of magnitude between the pre-filtration method and trawl net for the same sampling site.

365 For MPs, we calculated a flux between $4.9 \times 10^{13}$ and $6.2 \times 10^{14}$ items/year, increasing from

366 Upstream to Downstream 2. $\mu \mathrm{FTIR}$ analyses coupled with the analysis software siMPle gave 367 an order of magnitude for MP mass fluxes transported at each sampling site (Table 3). MP 368 mass fluxes ranged between 58 and 1675 tonnes/year and increased from Upstream to 369 Downstream 2. The MP mass fluxes at Downstream 2 are extremely high. The highest MP concentrations (Figure 3, Table 2 and Table S6) and highest flowrates were reported at this site, which explains the reported mass fluxes. As reported for the number of particles,

372 Downstream 2 mass fluxes may be significant due to the different WWTP effluents (Figure

373 1). These significant mass fluxes may indicate high MP loads derived from urban water from 374 the Paris megacity. Thus, MP mass fluxes are impacted by urbanisation. 
375 Table 3: Estimations of MF and MP fluxes for each sampling point

\begin{tabular}{|l|c|c|c|}
\cline { 2 - 4 } \multicolumn{1}{c|}{} & $\begin{array}{c}\text { MF Fluxes in } \\
\text { items/year }\end{array}$ & $\begin{array}{c}\text { MPs Fluxes in } \\
\text { items/year }\end{array}$ & $\begin{array}{c}\text { MPs Fluxes in } \\
\text { tonnes/year }\end{array}$ \\
\hline Upstream & $6.6-7.1 \times 10^{12}$ & $4.9-6.0 \times 10^{13}$ & $58-74$ \\
\hline Downstream 1 & $4.4-4.8 \times 10^{13}$ & $1.8-2.2 \times 10^{14}$ & $56-146$ \\
\hline Downstream 2 & $4.9-9.1 \times 10^{13}$ & $3.6-6.0 \times 10^{14}$ & $924-1675$ \\
\hline
\end{tabular}

376

377 The January-February 2018 flood event corresponded to $14.5 \%$ of the year (in time) but

378 contributed $40 \%$ of the microplastic and microfiber annual loads, indicating the important role

379 of flood events as microplastic inputs in the Seine River. This is consistent with the data

380 collected by Wagner et al. (2019), who found that $90 \%$ of the plastic load in freshwater could

381 be transported in $20 \%$ of the year. According to our results, we observed a significant

382 increase in MP mass fluxes from upstream to downstream sites, mainly caused by the

383 increase in flow rates and not by a significant concentration increase. For this reason, high

384 water levels may significantly increase the plastic load in freshwater. For macroplastic fluxes,

385 van Emmerik et al. (2019) observed an increase of one order of magnitude during high water

386 levels in the Seine River. According to Tramoy et al. (2020a), flood events may effectively

387 flush plastic debris from upstream to downstream regions owing to their high flow rates.

388 Tramoy et al. (2021, under review) estimated that the macroplastic mass fluxes from the

389 Seine River estuary to the ocean range between 100 and 200 metric tons per year. The high

390 value found in Downstream 2 is most likely linked to the significant mass concentrations and

391 high flowrates for this sampling point. Although MP mass concentrations are rarely assessed

392 in freshwater systems, our results are consistent with the estimations from Rodrigues et al.

393 (2018), but are one or two orders of magnitude higher than other estimations (Haberstroh et

394 al., 2021; Kataoka et al., 2019). These estimations may indicate significant plastic inputs

395 from the Greater Paris region. However, our estimation does not correspond to MP mass 
396 discharge from land to sea, but only reflects the MP mass flux at certain sampling points.

397 More data should be collected on plastic mass fluxes, particularly in urban rivers, to confirm 398 the significant microplastic loads we observed.

399 4. Conclusion

400 We evaluated the MF and MP concentrations at three different upstream to downstream 401 sampling sites during both low-flow conditions and a flood event. The results of this study 402 show that the concentrations are of the same order of magnitude regardless of the 403 hydrological conditions. The urbanisation gradient did not significantly influence these 404 concentrations. Similarly, the flood and urbanisation gradient did not significantly affect the 405 size and polymer distributions at the different sampling sites. PP, PE, and PES correspond 406 to more than $60 \%$ of all polymers found. However, MP mass fluxes are strongly impacted by 407 the urbanisation gradient, as we observed very high mass fluxes at the most downstream 408 sampling site (924-1675 tonnes/year at Downstream 2). The January-February 2018 flood 409 event, which corresponds to $14.5 \%$ of the year (in terms of time), contributed $40 \%$ of the MF 410 and MP loads in the Seine River. In the future, greater attention should be paid to flood 411 events, as they constitute major pathways for microlitter contamination. A better 412 understanding of MF and MP dynamics in freshwater environments is needed to evaluate 413 the impact of transitory events such as floods and significant rainfall events.

414 5. Acknowledgements

415 We would like to thank the Urban Pollutants Observatory (OPUR) project for its support and 416 the OSU-Efluve for access to the $\mu$ FTIR. We would also like to thank Mathilde Ropiquet and 417 Léa Parent for their contributions to the sampling campaigns and microfiber counts during 418 their internships. 
420

421

422

423

424

425

426

427

428

429

430

431

432

433

434

435

436

437

438

439

440

441

442

443

444

445

446

447

448

449

450

451

452

453

454

455

456

457

458

459

460

461

462

463

464

465

466

467

468

469

Allen, S., Allen, D., Phoenix, V.R., Le Roux, G., Durántez Jiménez, P., Simonneau, A., Binet, S., Galop, D., 2019. Atmospheric transport and deposition of microplastics in a remote mountain catchment. Nat. Geosci. 12, 339-344. https://doi.org/10.1038/s41561-019-0335-5

Blettler, M.C.M., Ulla, M.A., Rabuffetti, A.P., Garello, N., 2017. Plastic pollution in freshwater ecosystems: macro-, meso-, and microplastic debris in a floodplain lake. Environ. Monit. Assess. 189, 581. https://doi.org/10.1007/s10661-017-6305-8

Cole, M., Lindeque, P., Halsband, C., Galloway, T.S., 2011. Microplastics as contaminants in the marine environment: A review. Mar. Pollut. Bull. 62, 2588-2597. https://doi.org/10.1016/j.marpolbul.2011.09.025

de Carvalho, A.R., Garcia, F., Riem-Galliano, L., Tudesque, L., Albignac, M., ter Halle, A., Cucherousset, J., 2021. Urbanization and hydrological conditions drive the spatial and temporal variability of microplastic pollution in the Garonne River. Sci. Total Environ. 769. https://doi.org/10.1016/j.scitotenv.2020.144479

Dris, R., Gasperi, J., Mirande, C., Mandin, C., Guerrouache, M., Langlois, V., Tassin, B., 2017. A first overview of textile fibers, including microplastics, in indoor and outdoor environments. Environ. Pollut. 221, 453-458. https://doi.org/10.1016/j.envpol.2016.12.013

Dris, R., Gasperi, J., Rocher, V., Saad, M., Renault, N., Tassin, B., 2015. Microplastic contamination in an urban area: a case study in Greater Paris. Environ. Chem. 12, 592-599. https://doi.org/10.1071/EN14167

Dris, R., Gasperi, J., Tassin, B., 2018. Sources and Fate of Microplastics in Urban Areas: A Focus on Paris Megacity. Freshw. Microplastics 69-83. https://doi.org/10.1007/9783-319-61615-5 4

Gall, S.C., Thompson, R.C., 2015. The impact of debris on marine life. Mar. Pollut. Bull. 92, 170-179. https://doi.org/10.1016/j.marpolbul.2014.12.041

Haberstroh, C.J., Arias, M.E., Yin, Z., Wang, M.C., 2021. Effects of hydrodynamics on the cross-sectional distribution and transport of plastic in an urban coastal river. Water Environ. Res. 93, 186-200. https://doi.org/10.1002/wer.1386

Hitchcock, J.N., 2020. Storm events as key moments of microplastic contamination in aquatic ecosystems. Sci. Total Environ. 734, 139436. https://doi.org/10.1016/j.scitotenv.2020.139436

Horton, A.A., Walton, A., Spurgeon, D.J., Lahive, E., Svendsen, C., 2017. Microplastics in freshwater and terrestrial environments: Evaluating the current understanding to identify the knowledge gaps and future research priorities. Sci. Total Environ. 586, 127-141. https://doi.org/10.1016/j.scitotenv.2017.01.190

Hurley, R., Woodward, J., Rothwell, J., 2018. Microplastic contamination of river beds significantly reduced by catchment-wide flooding. Nat. Geosci. https://doi.org/10.1038/s41561-018-0080-1

Jamieson A. J., Brooks L. S. R., Reid W. D. K., Piertney S. B., Narayanaswamy B. E., Linley T. D., 2019. Microplastics and synthetic particles ingested by deep-sea amphipods in six of the deepest marine ecosystems on Earth. R. Soc. Open Sci. 6, 180667. https://doi.org/10.1098/rsos.180667

Kataoka, T., Nihei, Y., Kudou, K., Hinata, H., 2019. Assessment of the sources and inflow processes of microplastics in the river environments of Japan. Environ. Pollut. 244, 958-965. https://doi.org/10.1016/j.envpol.2018.10.111

Kirstein, I.V., Hensel, F., Gomiero, A., Iordachescu, L., Vianello, A., Wittgren, H.B., Vollertsen, J., 2021. Drinking plastics? - Quantification and qualification of microplastics in drinking water distribution systems by $\mu$ FTIR and Py-GCMS. Water Res. 188, 116519. https://doi.org/10.1016/j.watres.2020.116519 
Klein, S., Worch, E., Knepper, T.P., 2015. Occurrence and Spatial Distribution of Microplastics in River Shore Sediments of the Rhine-Main Area in Germany. Environ. Sci. Technol. 49, 6070-6076. https://doi.org/10.1021/acs.est.5b00492

Liu, C., Li, J., Zhang, Y., Wang, L., Deng, J., Gao, Y., Yu, L., Zhang, J., Sun, H., 2019. Widespread distribution of PET and PC microplastics in dust in urban China and their estimated human exposure. Environ. Int. 128, 116-124. https://doi.org/10.1016/j.envint.2019.04.024

Liu, F., Olesen, K.B., Borregaard, A.R., Vollertsen, J., 2019. Microplastics in urban and highway stormwater retention ponds. Sci. Total Environ. 671, 992-1000. https://doi.org/10.1016/j.scitotenv.2019.03.416

Mani, T., Burkhardt-Holm, P., 2020. Seasonal microplastics variation in nival and pluvial stretches of the Rhine River - From the Swiss catchment towards the North Sea. Sci. Total Environ. 707, 135579. https://doi.org/10.1016/j.scitotenv.2019.135579

Mani, T., Hauk, A., Walter, U., Burkhardt-Holm, P., 2015. Microplastics profile along the Rhine River. Sci. Rep. 5, 17988. https://doi.org/10.1038/srep17988

Mao, Y., Li, H., Gu, W., Yang, G., Liu, Y., He, Q., 2020. Distribution and characteristics of microplastics in the Yulin River, China: Role of environmental and spatial factors. Environ. Pollut. 265, 115033. https://doi.org/10.1016/j.envpol.2020.115033

Rodrigues, M.O., Abrantes, N., Gonçalves, F.J.M., Nogueira, H., Marques, J.C., Gonçalves, A.M.M., 2018. Spatial and temporal distribution of microplastics in water and sediments of a freshwater system (Antuã River, Portugal). Sci. Total Environ. 633, 1549-1559. https://doi.org/10.1016/j.scitotenv.2018.03.233

Roebroek, C.T.J., Harrigan, S., Emmerik, T.H.M. van, Baugh, C., Eilander, D., Prudhomme, C., Pappenberger, F., 2021. Plastic in global rivers: are floods making it worse? Environ. Res. Lett. 16, 025003. https://doi.org/10.1088/1748-9326/abd5df

Schmidt, L.K., Bochow, M., Imhof, H.K., Oswald, S.E., 2018. Multi-temporal surveys for microplastic particles enabled by a novel and fast application of SWIR imaging spectroscopy - Study of an urban watercourse traversing the city of Berlin, Germany. Environ. Pollut. 239, 579-589. https://doi.org/10.1016/j.envpol.2018.03.097

Tramoy, R., Gasperi, J., Colasse, L., Silvestre, M., Dubois, P., Noûs, C., Tassin, B., 2020a. Transfer dynamics of macroplastics in estuaries - New insights from the Seine estuary: Part 2. Short-term dynamics based on GPS-trackers. Mar. Pollut. Bull. 160, 111566. https://doi.org/10.1016/j.marpolbul.2020.111566

Tramoy, R., Gasperi, J., Colasse, L., Tassin, B., 2020b. Transfer dynamic of macroplastics in estuaries - New insights from the Seine estuary: Part 1. Long term dynamic based on date-prints on stranded debris. Mar. Pollut. Bull. 152, 110894. https://doi.org/10.1016/j.marpolbul.2020.110894

Treilles, R., Cayla, A., Gaspéri, J., Strich, B., Ausset, P., Tassin, B., 2020. Impacts of organic matter digestion protocols on synthetic, artificial and natural raw fibers. Sci. Total Environ. 748, 141230. https://doi.org/10.1016/j.scitotenv.2020.141230

Treilles, R., Gasperi, J., Gallard, A., Saad, M., Dris, R., Partibane, C., Breton, J., Tassin, B., 2021a. Microplastics and microfibers in urban runoff from a suburban catchment of Greater Paris. Sci. Total Environ.

Treilles, R., Gasperi, J., Saad, M., Tramoy, R., Breton, J., Rabier, A., Tassin, B., 2021b. Abundance, composition and fluxes of plastic debris and other macrolitter in urban runoff in a suburban catchment of Greater Paris. Water Res. 192, 116847. https://doi.org/10.1016/j.watres.2021.116847

van Emmerik, T., Kieu-Le, T.-C., Loozen, M., Oeveren, K., Strady, E., Bui, X.-T., Egger, M., Gasperi, J., Lebreton, L., Nguyen, P.-D., Schwarz, A., Slat, B., Tassin, B., 2018. A methodology to characterize riverine macroplastic emission into the ocean. Front. Mar. Sci. 5. https://doi.org/10.3389/fmars.2018.00372

van Emmerik, T., Tramoy, R., van Calcar, C., Alligant, S., Treilles, R., Tassin, B., Gasperi, J., 2019. Seine Plastic Debris Transport Tenfolded During Increased River Discharge. Front. Mar. Sci. 6. https://doi.org/10.3389/fmars.2019.00642 
Veerasingam, S., Mugilarasan, M., Venkatachalapathy, R., Vethamony, P., 2016. Influence of 2015 flood on the distribution and occurrence of microplastic pellets along the Chennai coast, India. Mar. Pollut. Bull. 109, 196-204.

Vilmin, L., 2014. Modélisation du fonctionnement biogéochimique de la Seine de l'agglomération parisienne à l'estuaire à différentes échelles temporelles (phdthesis). Ecole Nationale Supérieure des Mines de Paris.

Voies Navigables de France, 2020. Transport et tourisme fluvial : les chiffres clés 2019. Wagner, S., Klöckner, P., Stier, B., Römer, M., Seiwert, B., Reemtsma, T., Schmidt, C., 2019. Relationship between Discharge and River Plastic Concentrations in a Rural and an Urban Catchment. Environ. Sci. Technol. 53, 10082-10091. https://doi.org/10.1021/acs.est.9b03048

Watkins, L., Sullivan, P.J., Walter, M.T., 2019. A case study investigating temporal factors that influence microplastic concentration in streams under different treatment regimes. Environ. Sci. Pollut. Res. Int. https://doi.org/10.1007/s11356-019-04663-8

Witzig, C.S., Földi, C., Wörle, K., Habermehl, P., Pittroff, M., Müller, Y.K., Lauschke, T., Fiener, P., Dierkes, G., Freier, K.P., Zumbülte, N., 2020. When Good Intentions Go Bad-False Positive Microplastic Detection Caused by Disposable Gloves. Environ. Sci. Technol. 54, 12164-12172. https://doi.org/10.1021/acs.est.0c03742

Wong, G., Löwemark, L., Kunz, A., 2020. Microplastic pollution of the Tamsui River and its tributaries in northern Taiwan: Spatial heterogeneity and correlation with precipitation. Environ. Pollut. 260, 113935. https://doi.org/10.1016/j.envpol.2020.113935

Wu, P., Tang, Y., Dang, M., Wang, S., Jin, H., Liu, Y., Jing, H., Zheng, C., Yi, S., Cai, Z., 2020. Spatial-temporal distribution of microplastics in surface water and sediments of Maozhou River within Guangdong-Hong Kong-Macao Greater Bay Area. Sci. Total Environ. 717, 135187. https://doi.org/10.1016/j.scitotenv.2019.135187

Zhao, S., Zhu, L., Li, D., 2016. Microscopic anthropogenic litter in terrestrial birds from Shanghai, China: Not only plastics but also natural fibers. Sci. Total Environ. 550, 1110-1115. https://doi.org/10.1016/j.scitotenv.2016.01.112

Zheng, Y., Li, J., Sun, C., Cao, W., Wang, M., Jiang, F., Ju, P., 2021. Comparative study of three sampling methods for microplastics analysis in seawater. Sci. Total Environ. 765, 144495. https://doi.org/10.1016/j.scitotenv.2020.144495 
559 Table S1: Daily flowrates, water levels and sampling volumes corresponding to each sample 560 (data from http://hydro.eaufrance.fr)

\begin{tabular}{|c|c|c|c|c|c|}
\hline & & & Upstream & Downstream 1 & Downstream 2 \\
\hline \multirow{3}{*}{1} & \multirow{3}{*}{$01 / 26 / 2018$} & Flowrates $\left(\mathrm{m}^{3} / \mathrm{s}\right)$ & 280 & 1570 & 1880 \\
\hline & & Water level $(\mathrm{m})$ & 6.19 & 5.49 & 3.39 \\
\hline & & Sampling volume (L) & 23 & 27 & 19 \\
\hline \multirow{3}{*}{2} & \multirow{3}{*}{ 02/05/2018 } & Flowrates $\left(\mathrm{m}^{3} / \mathrm{s}\right)$ & 330 & 1460 & 1940 \\
\hline & & Water level $(\mathrm{m})$ & 6.28 & 5.28 & 5.03 \\
\hline & & Sampling volume (L) & 24 & 24 & 23 \\
\hline \multirow{3}{*}{ 2bis } & \multirow{3}{*}{$02 / 21 / 2018$} & Flowrates $\left(\mathrm{m}^{3} / \mathrm{s}\right)$ & 256 & - & - \\
\hline & & Water level $(\mathrm{m})$ & 6.19 & - & - \\
\hline & & Sampling volume (L) & 24 & - & - \\
\hline \multirow{3}{*}{3} & \multirow{3}{*}{ 07/17/2018 } & Flowrates $\left(\mathrm{m}^{3} / \mathrm{s}\right)$ & 45 & 155 & 241 \\
\hline & & Water level $(\mathrm{m})$ & 4.01 & 0.97 & 3.36 \\
\hline & & Sampling volume (L) & 21 & 20 & 20 \\
\hline
\end{tabular}

561

562 Table S2: Summary of microfibers and microplastics sizes collected during a flood event

563

\begin{tabular}{|l|c|c|r|r|r|}
\hline \multicolumn{1}{|c|}{ Microfibers } & $\mathbf{N}$ & $\begin{array}{c}\text { Mean } \\
(\mu \mathrm{m})\end{array}$ & $\begin{array}{c}\text { Standard } \\
\text { deviation }(\mu \mathrm{m})\end{array}$ & $\begin{array}{c}\text { Median } \\
(\mu \mathrm{m})\end{array}$ & $\begin{array}{c}\text { Interquartile } \\
\text { range }(\mu \mathrm{m})\end{array}$ \\
\hline Upstream & 164 & 4153 & 4388 & 2716 & 3092 \\
\hline Downstream 1 & 168 & 3762 & 3036 & 2670 & 2983 \\
\hline Downstream 2 & 123 & 3699 & 3254 & 2453 & 2863 \\
\hline
\end{tabular}

564

\begin{tabular}{|l|r|r|r|r|r|}
\hline Microplastics & $\mathbf{N}$ & $\begin{array}{c}\text { Mean } \\
(\boldsymbol{\mu \mathrm { m }})\end{array}$ & $\begin{array}{c}\text { Standard } \\
\text { deviation }(\boldsymbol{\mu \mathrm { m }})\end{array}$ & $\begin{array}{c}\text { Median } \\
(\boldsymbol{\mu \mathrm { m }})\end{array}$ & $\begin{array}{c}\text { Interquartile } \\
\text { range }(\boldsymbol{\mu \mathrm { m }})\end{array}$ \\
\hline Upstream & 158 & 278 & 351 & 171 & 185 \\
\hline Downstream 1 & 116 & 258 & 255 & 150 & 215 \\
\hline Downstream 2 & 80 & 243 & 201 & 163 & 198 \\
\hline
\end{tabular}

565 Table S3: Summary of microfibers and microplastics sizes collected during low flow

566 conditions

\begin{tabular}{|l|c|c|c|c|c|}
\hline \multicolumn{1}{|c|}{ Microfibers } & $\mathbf{N}$ & $\begin{array}{c}\text { Mean } \\
(\boldsymbol{\mu \mathrm { m }})\end{array}$ & $\begin{array}{c}\text { Standard } \\
\text { deviation }(\boldsymbol{\mu \mathrm { m }})\end{array}$ & $\begin{array}{c}\text { Median } \\
(\boldsymbol{\mu \mathrm { m }})\end{array}$ & $\begin{array}{c}\text { Interquartile } \\
\text { range }(\boldsymbol{\mu \mathrm { m }})\end{array}$ \\
\hline Upstream & 51 & 3923 & 2705 & 3482 & 3536 \\
\hline Downstream 1 & 86 & 3363 & 2531 & 2512 & 2608 \\
\hline Downstream 2 & 122 & 3221 & 2337 & 2687 & 2675 \\
\hline
\end{tabular}




\begin{tabular}{|l|l|r|r|r|r|}
\hline Microplastics & $\mathbf{N}$ & $\begin{array}{c}\text { Mean } \\
(\mu \mathrm{m})\end{array}$ & $\begin{array}{c}\text { Standard } \\
\text { deviation }(\mu \mathrm{m})\end{array}$ & \multicolumn{1}{c|}{$\begin{array}{c}\text { Median } \\
(\mu \mathrm{m})\end{array}$} & \multicolumn{2}{c|}{$\begin{array}{c}\text { Interquartile } \\
\text { range }(\mu \mathrm{m})\end{array}$} \\
\hline Upstream & 45 & 133 & 116 & 96 & 90 \\
\hline Downstream 1 & 27 & 124 & 91 & 96 & 56 \\
\hline Downstream 2 & 75 & 386 & 409 & 249 & 390 \\
\hline
\end{tabular}

569 Table S4: Details of the category "Other" from Figure 6

\begin{tabular}{|l|l|}
\hline Polymers from the category "Other" & Abbreviation \\
\hline Acrylonitrile butadiene styrene & ABS \\
\hline Cellulose Acetate & CA \\
\hline Polyacrylonitrile & PAN \\
\hline Polyamide & PA \\
\hline Polyurethane & PU \\
\hline Polyvinyl Acetate & PVAC \\
\hline Styrene butadiene rubber & SBR \\
\hline
\end{tabular}

570

571 Table S5 : Details of the polymers found in the different samples

\begin{tabular}{|l|c|l|}
\cline { 2 - 3 } \multicolumn{1}{c|}{} & Number of polymer types found & \multicolumn{1}{c|}{ Details } \\
\hline 260118_Upstream & 7 & CA, PAN, PE, PES, PP, PS, PVC \\
\hline 260118_Downstream 1 & 5 & ABS, PE, PP, PS, SBR \\
\hline 260118_Downstream 2 & 4 & PE, PES, PP, PS \\
\hline 050218_Upstream & 3 & PE, PES, PP \\
\hline 050218_Downstream 1 & 5 & PA, PE, PES, PP, PVAC \\
\hline 050218_Downstream 2 & 5 & PA, PE, PES, PP, PU \\
\hline 210218_Upstream & 6 & PAN, PE, PES, PP, PS, PVAC \\
\hline 170718_Upstream & 3 & PE, PES, PP \\
\hline 170718_Downstream 1 & 5 & PA, PE, PP, PS, PVC \\
\hline 170718_Downstream 2 & 5 & ABS, PE, PP, PS, PVC \\
\hline
\end{tabular}


574 Table S6: MF and MP concentrations (first and third quartile) for each sampling site

\begin{tabular}{|l|c|c|c|}
\cline { 2 - 4 } \multicolumn{1}{c|}{} & $\begin{array}{c}\text { First and third quartile } \\
\text { (concentration in } \\
\text { microfibers per liter) }\end{array}$ & $\begin{array}{c}\text { First and third quartile } \\
\text { (concentration in } \\
\text { microplastics per liter) }\end{array}$ & $\begin{array}{c}\text { First and third quartile } \\
\text { (concentration in } \mu \text { of } \\
\text { microplastics per liter) }\end{array}$ \\
\hline Upstream & $1.9-2.0$ & $14.3-17.4$ & $16.8-21.3$ \\
\hline Downstream 1 & $3.0-3.4$ & $12.3-15.6$ & $3.9-10.3$ \\
\hline Downstream 2 & $2.5-4.6$ & $18.5-30.4$ & $47.0-85.1$ \\
\hline
\end{tabular}

